\title{
Comparative Study of Single Dose Epidural Morphine and Intermittent Dose Morphine with Bupivacaine in Post Cesarean Analgesia
}

\author{
Agarwal K, ${ }^{1}$ Sharma M, ${ }^{1}$ Agarwal N, ${ }^{2}$ Agrawal VK, ${ }^{3}$ Agarwal A, ${ }^{4}$ \\ ${ }^{1}$ Dept of Obs/Gyn, ${ }^{2}$ Anesthesia, ${ }^{3}$ Community Medicine, ${ }^{4}$ Pediatrics, Rohilkhand Medical College Bareilly, UP
}

\begin{abstract}
Aims: Obstetric anesthesia presents a challenge to the anesthesiologist. The effective pain management allows the parturient adequate degree of comfort and promotes physical recovery and a sense of well being.

Methods: This randomized controlled study was designed to assess the analgesic efficacy and side effects of single dose direct epidural morphine (Group 1) versus intermittent 12 hourly epidural morphine with bupivacaine (Group2) for postoperative analgesia in lower segment caesarean section cases.

Results: Each group consisted of 36 patients. Demographic characteristics of two groups were comparable and differences among them were not statistically significant. Mean duration of analgesia was significantly longer in group one patients $(16.5 \pm 2.5)$ in comparison to group two patients $(11.5 \pm 1.5)$. Mean highest visual analogue scales (VAS scale) was significantly lower (3.2 \pm 0.9$)$ in group one patients in comparison of group two (6.7 \pm 0.8$)$ patients. Only $43 \%$ patient in group one required supplementary analgesic (Inj Paracetamole/ Diclofenac) and $71 \%$ required Inj epidural Morphine / Inj bupivacaine in group two . Mean number of supplementary analgesic required in group one was 0.7 and it was 1.8 in group two. There was no significant difference in nausea, vomiting, itching and pruritis in two groups of patients.
\end{abstract}

Conclusions: our study showed that the use of single dose epidural morphine was associated with lower pain scores at rest and movement when compared to intermittent epidural morphine with bupivacaine in post-caesarean section analgesia. Single dose epidural morphine was found more convenient, less cumbersome and less costly as compared to intermittent epidural morphine for post-caesarean section analgesia.

Keywords: Caesarean section, epidural analgesia, morphine

\section{INTRODUCTION}

Obstetric anesthesia presents a spectrum of challenges to the anesthesiologist not only in provision of acute intra partum labor analgesia but also in provision of postoperative analgesia. ${ }^{1}$ It has been well established that postoperative pain leads to patient discomfort, decreased level of satisfaction, prolonged recovery and higher health care cost. Specifically in the parturient inadequate postoperative

\section{CORRESPONDENCE}

Dr VK Agrawal

Department of Community Medicine,

Rohilkhand Medical College \& Hospital, Bareilly (UP)

Phone: 09368394443

Email: vijenderagrawal@yahoo.co.in pain control after cesarean section may interfere with ambulation, breast-feeding and early maternal bonding with the infant. The effective pain management does not necessarily make the parturient totally insensible to the fact that cesarean section was performed, but rather, it allows adequate degree of comfort and promotes physical recovery and a sense of well being. ${ }^{2}$ Effective postoperative analgesia can be provided with systemic administration of opioids and/or nonopioid analgesics as well as with epidural and spinal techniques. ${ }^{3-10}$ The American Academy 
Agarwal et al. Comparative Study of Singal Dose Eidural Morphine and Intermittent Dose Morphine with Bupivacaine...

of Pediatrics Committee on Drugs lists morphine, fentanyl and butorphanol as maternally administered opioids that are compatible with breast-feeding. ${ }^{11}$ This prospective randomized controlled study was designed to assess the analgesic efficacy and side effects of single dose direct epidural morphine versus intermittent epidural morphine with bupivacaine for postoperative analgesia in lower segment cesarean section cases.

\section{METHODS}

This study was conducted in a hospital of UP. It was designed in the form of a randomized control study. Approval for study was obtained from the institutional ethical committee and written informed consent from each patient was taken before the study. Postoperative visual analogue scales (VAS score) was considered the primary end point in determination of sample size. It was determined that a sample size of 36 patients in each group would have $80 \%$ power to detect $30 \%$ difference in VAS while limiting the type I error less than $5 \%$. Seventy two patients at term American Society of Anesthesiology Classification (ASA-I \& ASA-II) scheduled for lower segment cesarean section under epidural anesthesia were selected by simple random sample technique and divided into two groups. Patients with complicated pregnancy, acute fetal distress, history of hypersensitivity to opioids /local anesthetics were excluded. In the pre-anesthetic visit, all the patients were made familiar with the study plan and the different visual analogue scales (VAS) to be used in the assessment by the investigators. Respiratory rate, arterial blood pressure, peripheral arterial saturation and heart rate were monitored throughout the peri-operative period.

Epidural anesthesia was used for surgery. Intensity of postoperative pain during the first 24 hours was assessed at hourly interval using a visual analogue pain score (VAS), ${ }^{12} 0$ denotes "no pain" while 10 denotes "worst pain imaginable". When the patient was asleep, no VAS assessments were made and VAS of 0 was given. Group one was scheduled to receive single dose of $1.20 \mathrm{mg}$ epidural morphine (dissolved in $15 \mathrm{ml}$ of $2 \%$ Inj lignocaine) and subsequently Inj Paracetamole/ Inj Diclofenac when the pain score was 4 or more, or if the patient requested analgesia (whichever occurred earlier). Total supplementary analgesics (Inj Paracetamole/ Inj Diclofenac) required was recorded. Group two was scheduled to receive bolus dose of $15 \mathrm{ml}$ of $2 \%$ Inj lignocaine epidurally initially and $0.5 \mathrm{mg}$ epidural morphine (dissolved in $10 \mathrm{ml}$ of $0.125 \% \mathrm{Inj}$ bupivacaine) subsequently. If patient requested analgesia at interval less than 12 hour Inj bupivacaine alone was given. Total supplementary analgesics (Inj morphine/ inj bupivacaine) for group 2 was also recorded.

The onset of analgesia was defined as the time from injection of the study medication to first reduction in pain intensity by at least 1 in VAS; and the duration of analgesia was defined as the time between the onset of analgesia and either a return to baseline VAS or the time when additional pain medication was requested, whichever occurred first. The occurrence of nausea and vomiting, pruritus, shivering and respiratory depression (respiratory rate $<12 /$ minute), sedation and hypotension was noted up to 24 hours following administration of the study medication. The collected data was analyzed using the Statistical Package for Social Science (version 10.0 for Windows, SPSS). Analysis of variance /Chi square test was used to compare the variables between groups. P value of $<0.05$ was considered significant.

\section{RESULTS}

A total of 72 patients were studied. Each group consisted of 36 patients. Demographic characteristics (age, weight, height and systolic and diastolic BP) of two groups as mean, standard deviation and range are depicted in table 1.

\section{Table 1: Demographic characteristics of Patients}

\begin{tabular}{|c|c|c|c|c|c|}
\hline & $\begin{array}{l}\text { Age in } \\
\text { Years } \\
\{\text { Mean } \\
\pm \text { SD } \\
\text { (Range) }\end{array}$ & $\begin{array}{l}\text { Weight in } \\
\mathrm{Kg}\{\text { Mean } \\
\pm \mathrm{SD} \\
\text { (Range)\} }\end{array}$ & $\begin{array}{l}\text { Height in } \\
\mathrm{Cm}\{\text { Mean } \\
\pm \mathrm{SD} \\
\text { (Range)\} }\end{array}$ & $\begin{array}{l}\text { Systolic BP } \\
\{\text { Mean } \pm \\
\text { SD (Range)\} }\end{array}$ & $\begin{array}{l}\text { Dystolic } \\
\text { BP \{Mean } \\
\pm \text { SD } \\
\text { (Range) }\}\end{array}$ \\
\hline $\begin{array}{l}\text { Group } 1 \\
\text { (N 36) } \\
\text { (single dose } \\
\text { Morphine) }\end{array}$ & $\begin{array}{l}25.71 \pm 3.56 \\
(20-35)\end{array}$ & $\begin{array}{l}60.15 \pm 6.18 \\
(52-74)\end{array}$ & $\begin{array}{l}160.58 \pm 4.16 \\
(152-170)\end{array}$ & $\begin{array}{l}119.64 \pm 13.08 \\
(104-140)\end{array}$ & $\begin{array}{l}78.18 \pm 11.49 \\
(70-98)\end{array}$ \\
\hline $\begin{array}{l}\text { Group 2 } \\
\text { (N 36) } \\
\text { (intermittent } \\
\text { morphine } \\
\text { with } \\
\text { bupivacaine) }\end{array}$ & $\begin{array}{l}26.46 \pm 4.28 \\
(20-34)\end{array}$ & $\begin{array}{l}61.92 \pm 10.86 \\
(49-72)\end{array}$ & $\begin{array}{l}160.84 \pm 2.93 \\
(157-165)\end{array}$ & $\begin{array}{l}120.28 \pm 7.12 \\
(110-136)\end{array}$ & $\begin{array}{l}76.10 \pm 5.77 \\
(70-88)\end{array}$ \\
\hline$P$ value & $\begin{array}{l}\text { Not } \\
\text { significant }\end{array}$ & $\begin{array}{l}\text { Not } \\
\text { significant }\end{array}$ & $\begin{array}{l}\text { Not } \\
\text { significant }\end{array}$ & $\begin{array}{l}\text { Not } \\
\text { significant }\end{array}$ & $\begin{array}{l}\text { Not } \\
\text { significant }\end{array}$ \\
\hline
\end{tabular}

Demographic characteristics of two groups are comparable and differences among them were not statistically significant.

Table 2 gives the comparison of postoperative analgesia in two groups of patients. Mean duration of analgesia was significantly longer in group one patients $(16.5 \pm 2.5)$ receiving single dose epidural morphine in comparison to group two patients $(11.5 \pm 1.5)$ receiving intermittent epidural morphine with bupivacaine (Fig 1). 


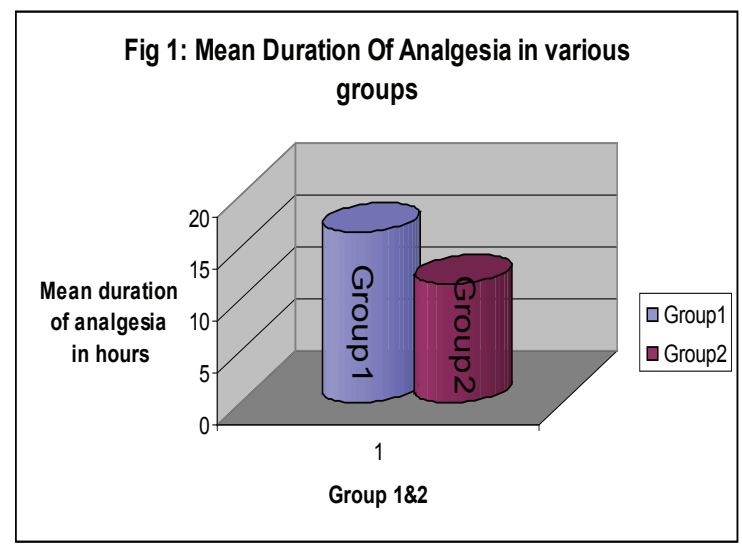

Mean highest pain score (VAS scale) was significantly lower $(3.2 \pm 0.9)$ in group one patients in comparison of group two $(6.7 \pm 0.8)$ patients. Only $43 \%$ patient in group one required supplementary analgesic (Inj Paracetamol/ Diclofenac and $71 \%$ required Inj epidural Morphine / Inj bupivacaine in group 2. These differences in two groups were found statistically significant. Mean number of supplementary analgesic required in group one was 0.7 and it was 1.8 in group two.

Table 2: Comparison of Postoperative analgesia in two groups

\begin{tabular}{|c|c|c|c|}
\hline Effect & Group 1 & Group 2 & P Value \\
\hline & $\begin{array}{l}\text { (single dose } \\
\text { Morphine) } \\
\text { (N 36) }\end{array}$ & $\begin{array}{l}\text { (intermittent } \\
\text { Morphine with } \\
\text { bupivacaine) } \\
\text { (N 36) }\end{array}$ & \\
\hline $\begin{array}{l}\text { Duration of } \\
\text { Analgesia ( Hours) } \\
\text { after Ist dose Mean } \\
\pm \text { SD (Range) }\end{array}$ & $\begin{array}{l}16.5 \pm 2.5 \\
(11.5-21.5)\end{array}$ & $\begin{array}{l}11.5 \pm 1.5 \\
(8.5-14.5)\end{array}$ & $\begin{array}{l}<0.05 \\
\text { Significant }\end{array}$ \\
\hline $\begin{array}{l}\text { Highest Pain Score } \\
\text { VAS Scale }(0-10) \\
\text { Mean } \pm \text { SD }\end{array}$ & $3.2 \pm 0.9$ & $5.7 \pm 1.4$ & $\begin{array}{l}<0.05 \\
\text { Significant }\end{array}$ \\
\hline $\begin{array}{l}\text { Proportion of } \\
\text { Patients requiring } \\
\text { supplementary } \\
\text { after Ist dose }\end{array}$ & $\begin{array}{l}43 \% \text { (Inj } \\
\text { Paracetamole/ } \\
\text { Diclofenac) }\end{array}$ & $\begin{array}{l}71 \% \text { (Inj } \\
\text { epidural } \\
\text { Morphine / Inj } \\
\text { bupivacaine ) }\end{array}$ & $\begin{array}{l}<0.05 \\
\text { Significant }\end{array}$ \\
\hline $\begin{array}{l}\text { Average Number } \\
\text { of supplementary } \\
\text { analgesic injection } \\
\text { per patient after Ist } \\
\text { dose }\end{array}$ & 0.7 & 1.8 & $\begin{array}{l}<0.05 \\
\text { gnificant }\end{array}$ \\
\hline
\end{tabular}

Symbols / denotes and or, Symbol " $<$ " denotes lesser than

Table 3 depicts comparison of side effects of drugs in two groups of patients. There was no significant difference in nausea, vomiting, itching and pruritis in two groups of patients. Incidence of respiratory depression, sedation and hypotension were nil in two groups of patients.
Table 3: Comparison of side Effects in two Groups of Patients

\begin{tabular}{llll}
\hline $\begin{array}{l}\text { Side Effect } \\
\text { Percentage) }\end{array}$ & $\begin{array}{l}\text { Group 1 } \\
\text { (single dose } \\
\text { Morphine) } \\
\text { (N 36) }\end{array}$ & $\begin{array}{l}\text { Group 2 } \\
\text { (intermittent } \\
\text { Morphine with } \\
\text { bupivacaine) } \\
\text { (N 36) }\end{array}$ & P value \\
\hline $\begin{array}{l}\text { Nausea } \\
\text { (Percentage) }\end{array}$ & 6 & 3 & $>0.5 \mathrm{NS}$ \\
$\begin{array}{l}\text { Vomiting( } \\
\text { Percentage) }\end{array}$ & 3 & 0 & $>0.5 \mathrm{NS}$ \\
$\begin{array}{l}\text { Itching } \\
\text { Percentage) }\end{array}$ & 3 & 3 & $>0.5 \mathrm{NS}$ \\
$\begin{array}{l}\text { Pruritus } \\
\text { (Percentage) }\end{array}$ & 6 & 3 & $>0.5 \mathrm{NS}$ \\
$\begin{array}{l}\text { Respiratory } \\
\text { Depression } \\
\text { (Percentage) }\end{array}$ & 0 & 0 & $>0.5 \mathrm{NS}$ \\
$\begin{array}{l}\text { Sedation } \\
\text { (Percentage) }\end{array}$ & 0 & 0 & $>0.5 \mathrm{NS}$ \\
$\begin{array}{l}\text { Hypotension } \\
\text { (Percentage) }\end{array}$ & 0 & $0.5 \mathrm{NS}$ \\
\hline
\end{tabular}

\section{DISCUSSION}

Epidural morphine was first reported as an effective analgesic in humans by Behar et al. ${ }^{13}$ In 1979, reports of its use in obstetric patients were published. ${ }^{14}$ It has been reported that more than $90 \%$ of obstetric anesthesiologists administer subarachnoid or epidural opioids in parturients undergoing cesarean section under spinal, epidural or combined spinal epidural anesthesia. ${ }^{15,16}$ Craig et al observed that degree and duration of analgesia increase as the dose of epidural morphine increases over the range of 0 to $3.75 \mathrm{mg}$. Even the smallest dose $1.25 \mathrm{mg}$, had a modest patient controlled analgesia that persisted through the 24-hour study period. In their study little relation was found between dose and side effects (nausea, vomiting, itching and pruritis) over the range studied. They observed for optimal analgesia, augmentation of epidural morphine with systemic analgesics or other epidural medications may be necessary. ${ }^{17}$ Our study indicates that the degree and duration of analgesia was better with $1.20 \mathrm{mg}$ single dose epidural morphine in comparison to intermittent morphine and requirement of supplementary / rescue analgesic was significantly less in patients receiving single dose epidural morphine. In our study there was no significant difference in nausea, vomiting, itching and pruritus in two groups of patients. Craig et $\mathrm{al}^{17}$ also reported that side effects of epidural morphine were not dose related. Incidence of respiratory depression, sedation and hypotension were nil in two groups of patients. It had been reported that epidural opioid offers several advantages to parturients recovering from cesarean section. These include excellent postoperative analgesia with a decrease in total dose of opioids required, a low level of sedation, minimal accumulation of the drug in breast milk, facilitation of early ambulation and early return of bowel function. ${ }^{18}$ In 
our study also single dose of epidural morphine was found more convenient, less cumbersome and less costly to intermittent epidural morphine with bupivacaine for postcesarean section analgesia.

\section{CONCLUSIONS}

In conclusion, our study showed that the use of single dose epidural morphine was associated with lower pain scores at rest and movement when compared to intermittent epidural morphine with bupivacaine in postcaesarean section analgesia. The use of nonsteroidal antiinflammatory drugs (NSAIDs) enhanced the efficacy of analgesia of single dose epidural morphine. We did not detect any severe side effects (e.g. respiratory depression and sedation) with the doses of single dose epidural morphine used. There was no significant difference in nausea, vomiting, itching and pruritus in two groups of patient. Single dose epidural morphine was found more convenient, less cumbersome and less costly to intermittent epidural morphine for post-caesarean section analgesia.

\section{REFERENCES}

1. Kuczkowski KM. Obstetric anesthesia: past present and future. Matern Fetal Neonatal Med. 2009;22(10):819-22.

2. Leung A. Postoperative Pain Management in Obstetric - New Challenges and Solutions. J Clin Anesth. 2004;16(1):57-65.

3. Vercauteren M, Vereecken K, La Malfa M, Coppejans H, Adriaensen H. Cost-effectiveness of analgesia after Caesarean section. A comparison of intrathecal morphine and epidural PCA. Acta Anaesthesiol Scand. 2002;46(1):85-9.

4. Draisci G, Frassanito L, Pinto R, Zanfini B, Ferrandina G, Valente A. Safety and effectiveness of co administration of intrathecal sufentanil and morphine in hyperbaric bupivacaine-based spinal anesthesia for cesarean section. J Opioid Manag. 2009;5(4):197 202.

5. Bamigboye AA, Hofmeyr GJ. Local anaesthetic wound infiltration and abdominal nerves block during caesarean section for postoperative pain relief. Cochrane Database Syst Rev. 2009;8(3):CD006954.

6. Benhamou D, Bouaziz H, Chassard D, Ducloy JC, Fuzier V, Laffon $M$, et al. Anaesthetic practices for scheduled caesarean delivery: a 2005 French national survey. Eur J Anaesthesiol. 2009;26(8):694700.

7. Lavand'homme PM, Roelants F, Waterloos H, Collet V, De Kock MF. An evaluation of the postoperative antihyperalgesic and analgesic effects of intrathecal clonidine administered during elective cesarean delivery. Anesth Analg. 2008;107:948-55.

8. Carvalho B, Roland LM, Chu LF, Campitelli VA 3rd, Riley ET. Singledose, extended-release epidural morphine (DepoDur) compared to conventional epidural morphine for post-cesarean pain. Anesth Analg. 2007;105(1):176-83.

9. Van Tuijl I, van Klei WA, van der Werff DB, Kalkman CJ. The effect of addition of intrathecal clonidine to hyperbaric bupivacaine on postoperative pain and morphine requirements after Caesarean section: a randomized controlled trial. Br J Anaesth. 2006;97(3):36570.
10. Dualé $C$, Frey $C$, Bolandard F, Barrière A, Schoeffler P. Epidural versus intrathecal morphine for postoperative analgesia after Caesarean section. Br J Anaesth. 2003;91:690-4.

11. Ito $S$, Lee A. Drug excretion into breast milk-overview. Adv Drug Deliv Rev. 2003;55(5):617-27.

12. DeLoach $L$, Higgins MS, Caplan AB, Stiff JL. The visual analogue scale in the immediate postoperative period: intra-subject variability and correlation with a numeric scale. Anesth Analg. 1998;86(1):102-6.

13. Behar M, Magora F, Olshwang D, Davidson TT. Epidural morphine in treatment of pain. Lancet. 1979;1(8115):527-8.

14. Baraka A, Noueihid RD, Haji S. Intrathecal injection of morphine for obstetric analgesia. Anesthesiology. 1981;54(2):136-40.

15. Kuczkowski KM. Postoperative pain control in the parturient: new challenges (and their solutions). J Clin Anesth. 2004;16(1):1-3

16. Leung A. Postoperative Pain Management in Obstetric - New Challenges and Solutions. J Clin Anesth. 2004;16(1):57-65.

17. Craig MP, Wallace MN, Gretchen VM, Diane M. Postcesarean Epidural Morphine: A Dose-Response Study. Anesth Analg. 2000;90(4):887-91.

18. Draisci G, Frassanito L, Pinto R, Zanfini B, Ferrandina G, Valente A. Safety and effectiveness of co administration of intrathecal sufentanil and morphine in hyperbaric bupivacaine-based spinal anesthesia for cesarean section. J Opioid Manag. 2009;5(4):197 202 